\title{
Synthesis and Characterization of Calcium Phosphate Compounds with Strontium and Magnesium Ionic Substitutions
}

\author{
Síntetis y Caracterización del Compuestos de Fosfato de Calcio \\ con Substituto Iónico de Estroncio y Magnesio \\ Jose da Silva Rabelo Neto",**; Thaiane Balesteri Knopf,"**; Marcio Celso Fredel*; \\ Sergio Olate $\mathrm{e}^{* * *, * * * *, * * * * * *}$ \& Paulo H. de Moraes ${ }^{* * * * * * *}$
}

RABELO NETO, J. S.; KNOPF, T. B.; FREDEL, M. C.; OLATE, S. \& DE MORAES, P. H. Synthesis and characterization of calcium phosphate compounds with strontium and magnesium ionic substitutions. Int. J. Morphol., 33(3):1189-1193, 2015.

SUMMARY: Bioceramics offer advantages in the repair and regeneration of hard tissues and are used as bone void fillers and particulate fillers in bone cements with surgical applications. Regeneration and osteosynthesis stimulation via the release of essential ions such as strontium $\left(\mathrm{Sr}^{2+}\right)$ and magnesium $\left(\mathrm{Mg}^{2+}\right)$ is a relatively new field. Therefore, there is great interest in investigating various ionic substitutions on crystallographic structure and characteristics for use in osteoporosis prevent and increase bone formation and decrease bone resorption. In this study, we synthesize calcium phosphate samples with $\mathrm{Sr}^{2+}$ and $\mathrm{Mg}^{2+}$ ionic substitutions. The samples are characterized using X-ray diffraction, Fourier transform infrared spectroscopy, and inductively coupled plasma mass spectroscopy. Hydroxyapatite, beta tricalcium phosphate, and amorphous phases were observed. Depending on the ionic substitution, the crystal size and crystallinity varied from $22 \mathrm{~nm}$ to $130 \mathrm{~nm}$ and from $84 \%$ to $99.6 \%$, respectively. The Ca/P ratio ranged from 0.72 to 1.82 . The results demonstrated the effect of $\mathrm{Sr}^{2+}$ and $\mathrm{Mg}^{2+}$ inclusions in calcium phosphate on important parameters used in several bioceramic applications.

KEY WORDS: Calcium phosphate; Biomaterials; Bioceramics; Hydroxyapatite.

\section{INTRODUCTION}

Hydroxyapatite ( $\left.\mathrm{HAP}, \mathrm{Ca}_{10}\left(\mathrm{PO}_{4}\right)_{6}(\mathrm{OH})_{2}\right)$ is one of the most attractive materials for bone implants because of its compositional and biological similarity to native tissues (Weiner \& Addadi, 1997). Bone is an inorganic-bioorganic composite material consisting mainly of collagen proteins and HAP, and its properties depend intimately on its nanoscale structures. Researchers are particularly interested in the structure, surface roughness, chemistry, and mechanical properties of biomaterials biological matter (Dorozhkin, 2009). Nano-HAP (n-HAP) particles exhibit improved biological and mechanical properties compared with conventional HAP (Zhang et al., 2012). SrHAP is frequently used as a drug in osteoporosis therapy (Schumacher et al., 2013; Park et al., 2013). Spinal cord injuries predispose the patient to the occurrence of different diseases, including disuse osteoporosis due alterations in calcium metabolism (Lee et al., 1997). Some articles suggest that hydroxyapatite implant is no adequate in new bone formation and osseointegration (da Cunha et al., 2015). However, some studies suggest that strontium administration has been show induce a significant increase in bone mass and bone strength by a dual mechanism of action: inhibition of bone resorption and augmentation of bone formation in both normal or ovariectomized animals (Capuccini et al., 2009).

Even small substitutions have been shown to have significant effects on the thermal stability, solubility and osteoclastic and osteoblastic responses in vitro, and on degradation and bone regeneration in vivo (Shepherd et al., 2012). Additionally, other studies have reported increased solubility and reduced thermal stability when using magnesium $\left(\mathrm{Mg}^{2+}\right)$ to form $\mathrm{Mg}$-HAP, which exhibits good biocompatibility and no genotoxicity, carcinogenicity, or toxicity (Landi et al., 2008). $\mathrm{Mg}$ is the main ion replacing $\mathrm{Ca}^{2+}$ in biological apatite and the amount at the beginning of

* CERMAT - Center for Research in Ceramics and Composite Materials, Department of Materials Engineering, Federal University of Santa Catarina, Florianópolis, Santa Cataria, Brazil.

** INNOVACURA BIOMATERIAIS LTDE-ME, Pedra Branca University city, Palhoça-SC, Brazil.

*** Division of Oral and Maxillofacial Surgery, Universidad de La Frontera, Temuco, Chile.

**** Center for Biomedical Research, Universidad Autónoma de Chile, Temuco, Chile.

****** Fellow Research, Universidad Científica del Sur, Lima, Perú.

******* Division of Oral and Maxillofacial Surgery, Casa de Saúde de Santos, São Paulo, Brazil. 
the calcification process and decreases with increasing calcification. Mg plays also an important role in bone metabolism, since it influences the bone growth by acting on osteoblast and osteoclast activities and it can prevent possible risk factors for osteoporosis in humans (Iafisco et al. 2014).

The incorporation of several ions in the HAP crystal lattice has been observed to affect its crystalline structure, crystal morphology (shape, particle size, and crystal orientation), and physical-chemical properties such as solubility and mechanical properties (hardness), thus affecting the bioactivity of the material (Leventouri 2006). Therefore, there is great research interest concerning different crystallographic substitutions in HAP crystals. Comprehensive studies on bone and synthetic apatites have led to the conclusion that bone mineral is not pure HAP but is associated with minor elements (e.g., $\mathrm{CO}_{3}^{2-}, \mathrm{HPO}^{2-}{ }_{4}, \mathrm{Na}^{+}$, and $\mathrm{Mg}^{2+}$ ) and trace elements (e.g., $\mathrm{Sr}^{2+}, \mathrm{K}^{+}, \mathrm{Cl}^{-}$, and $\mathrm{F}^{-}$) (Yao et al., 2009). The crystal structure properties of natural and synthetic HAPs have been studied extensively because functions such as the solubility and bioactivity of synthetic materials are controlled by crystallographic structure of these materials (Leventouri, 2006).

In this study, we prepared doped calcium phosphate through ionic substitution with $\mathrm{Sr}^{2+}$ and $\mathrm{Mg}^{2+}$ inclusions during the preparation process. Our results provide insights concerning the transformation phases of the calcium phosphate biomaterial family.

\section{MATERIAL AND METHOD}

Calcium phosphate with $\mathrm{Sr}^{2+}$ or $\mathrm{Mg}^{2+}$ ion substitutions was synthesized using the solution precipitation method. The calcium phosphate was prepared by chemical precipitation of calcium nitrate $\left(\mathrm{Ca}\left(\mathrm{NO}_{3}\right)_{2}\right)$, ammonium phosphate $\left(\left(\mathrm{NH}_{4}\right)_{2} \mathrm{HPO}_{4}\right)$, and Strontium nitrate $\left(\mathrm{Sr}\left(\mathrm{NO}_{3}\right)_{2}\right)$ or magnesium nitrate $\left(\left(\mathrm{Mg}\left(\mathrm{NO}_{3}\right)_{2}\right)\right.$ solutions. $\mathrm{NH}_{4} \mathrm{OH}$ solution was used to adjust the $\mathrm{pH}$. The reaction was performed at $\mathrm{pH} 10$ at room temperature, with a precipitation rate of $\sim 2 \mathrm{ml} / \mathrm{min}$ and magnetic stirring of $300 \mathrm{rpm}$. The samples were labeled with respect to distribution molarity $(\mathrm{Ca}+\mathrm{Sr}) / \mathrm{P}$ or $(\mathrm{Ca}+\mathrm{Mg}) / \mathrm{P}$, whereas the samples were prepared using the distribution molarity relations $\mathrm{A}=4, \mathrm{~B}=5$, and $\mathrm{C}=6$ respectively, $0.1 \mathrm{M}$, $0.2 \mathrm{M}$ and $0.3 \mathrm{M}$ of $\operatorname{Sr}\left(\mathrm{NO}_{3}\right)_{2}$ and $\mathrm{D}=1, \mathrm{E}=2$, and $\mathrm{F}=4$ respectively $0.025 \mathrm{M}, 0.05 \mathrm{M}$ and $0.1 \mathrm{M}$ of $\mathrm{Mg}\left(\mathrm{NO}_{3}\right)_{2}$. After synthesis, the samples were subjected to aging for $48 \mathrm{~h}$. The samples were thenfiltered and calcinated at $500{ }^{\circ} \mathrm{C}$ for $2 \mathrm{~h}$.

$\mathrm{X}$-ray diffraction (XRD) analysis was performed with $\mathrm{Cu} \mathrm{K} \alpha$ radiation $(\lambda=1.54056 \AA$ ) using a Philips X'Pert diffractometer. The XRD patterns were collected from $10^{\circ}$ to $60^{\circ} 2 \mathrm{q}$ with a step size of $0.02^{\circ}$ and time per step of $3 \mathrm{~s}$. The fraction of crystallinity phase $\left(\mathrm{X}_{\mathrm{c}}\right)$ of the calcium phosphates powders was evaluated by the following equation (Landi $e t$ al., 2000; Ungureanu et al., 2011):

$$
X_{c}=100 . \frac{I_{300}-V_{112} / 300}{I_{300}},[\%]
$$

Where is the intensity of (300) diffraction peak and the intensity of the hollow between (112) and (300) diffraction peaks of hydroxyapatite. The crystallite size $(t)$ of hydroxyapatite powder has been calculated based on Scherrer's equation (Bouyer et al., 2000):

$$
\tau=\frac{K \cdot \lambda}{W \cdot \cos (\theta)},(n m)
$$

Where: $\mathrm{K}=$ constant dependent on crystalline shape, $0.8<\mathrm{K}<1.1, \mathrm{~K}=0.94$ for FWHM of spherical crystals with cubic symmetry; $\lambda$ is the wavelength of monochromatic radiation $(\lambda=1.54056 \AA)$. W is defined as the full width of peak from the intensity distribution pattern measured at half of the maximum intensity value. This value is the difference between two 2 theta values, in radians; and q is the Bragg angle, in degree.

Pellets were prepared by pressing $100 \mathrm{mg}$ samples into $\mathrm{KBr}$ and $5 \mathrm{mg}$ of the material using a mechanical press with 4 $\mathrm{t}$ of force for $10 \mathrm{~min}$. The samples obtained were subjected to Fourier transform infrared (FTIR) spectroscopy using a Thermo Nicolet 6700 FTIR spectrometer (USA) in scanning transmission mode with $6 \mathrm{~cm}^{-1}$ resolution. The FTIR spectra were collected from $4000 \mathrm{~cm}^{-1}$ to $400 \mathrm{~cm}^{-1}$, with 100 scans per measurement. Inductively coupled plasma mass spectrometry (ICP-MS), using a Shimadzu ICPM-8500 spectrometer, was conducted to determine the concentrations of chemical elements in the prepared samples.

\section{RESULTS}

The ICP results presented in Table I demonstrate that $\mathrm{Sr}^{2+}$ enters the $\mathrm{Ca} 1$ site because, in addition to a Ca decrease, a $P$ decrease is observed. However, at a certain moment, because of the $\mathrm{Ca}-\mathrm{PO}_{4}$ bond breaking caused by the release of $\mathrm{PO}_{4}$ and the excess of $\mathrm{Sr}^{2+}$, a new crystallographic phase forms. However, the structure related to hydroxyapatite remains, ensuring the characteristics of the natural material with $\mathrm{Sr}^{2+}$ ions substitutions to perform preventive actions to osteoporosis.

When analyzing the vibrational bands of the samples doped with $\mathrm{Mg}^{2+}$, as observed in Figure 1, we realized that 
RABELO NETO, J. S.; KNOPF, T. B.; FREDEL, M. C.; OLATE, S. \& DE MORAES, P. H. Synthesis and characterization of calcium phosphate compounds with strontium and magnesium ionic substitutions. Int. J. Morphol., 33(3):1189-1193, 2015

Table I. Chemical element concentrations and $\mathrm{Ca} / \mathrm{P}$ ratios in the calcium phosphate samples.

\begin{tabular}{|c|c|c|c|c|c|c|c|}
\hline $\begin{array}{l}\text { Element } \\
\text { concentration } \\
(\mathrm{mg} / \mathrm{g})\end{array}$ & HAP pure & $\mathbf{A}$ & B & $\mathbf{C}$ & D & $\mathbf{E}$ & $\mathbf{F}$ \\
\hline $\mathrm{Ca}$ & $235.14 \pm 8.10$ & $201.28 \pm 3.53$ & $212.99 \pm 5.83$ & $218.14 \pm 4.29$ & $225.78 \pm 5.91$ & $139.36 \pm 3.24$ & $127.66 \pm 1.99$ \\
\hline $\mathrm{P}$ & $131.15 \pm 2.32$ & $113.32 \pm 1.69$ & $102.80 \pm 2.15$ & $119.97 \pm 2.12$ & $137.1 \pm 3.63$ & $171.30 \pm 2.78$ & $176.06 \pm 3.36$ \\
\hline $\mathrm{Sr}$ & $0.110 \pm 0.0001$ & $126.91 \pm 1.71$ & $172.57 \pm 3.35$ & $196.16 \pm 2.31$ & --- & --- & -- \\
\hline $\mathrm{Mg}$ & $0.36 \pm 0.01$ & --- & --- & --- & $24.73 \pm 0.10$ & $104.49 \pm 0.47$ & $119.85 \pm 0.49$ \\
\hline $\mathrm{Ca} / \mathrm{P}$ & 1.79 & 1.77 & 2.07 & 1.82 & 1.65 & 0.81 & 0.72 \\
\hline
\end{tabular}

there were substitutions in the connection sites with phosphate, which would release $\mathrm{Ca}^{2+}$ ions and affect the chemical composition of the material, leading to the formation of new phases. In contrast, samples $E$ and $F$ were amorphous with $\beta$ TCP peaks. The type B carbonate exhibited bands at approximately 1455,1410 , and $873 \mathrm{~cm}^{-1}$. Then, substitution of $\mathrm{Ca}^{2+}$ by $\mathrm{Sr}^{2+}$ occurred at these sites and decreased the $\mathrm{Ca} / \mathrm{P}$ ratio by changing the crystalline structure of HAP to $\beta$-TCP.

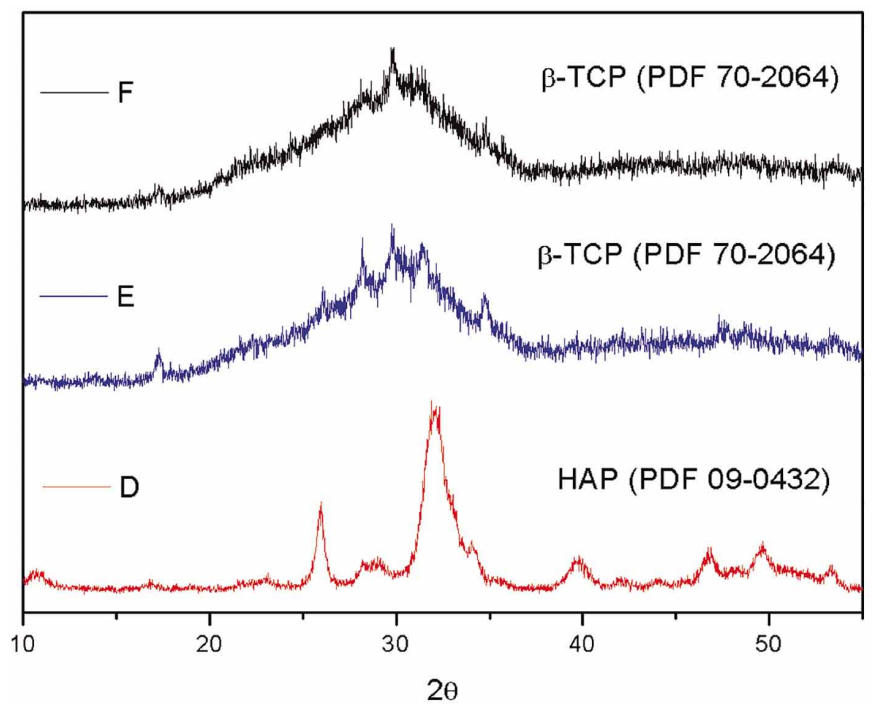

Fig. 1. XRD patterns of samples (D), (E), and (F) revealing HAP and $\beta$-TCP crystallographic phases after $\mathrm{Mg}$ ionic substitutions.

\section{DISCUSSION}

Our results revealed the effect of $\mathrm{Sr}^{2+}$ and $\mathrm{Mg}$ inclusions on the properties of the calcium phosphate family of bioceramics. In the samples doped with $\mathrm{Sr}^{2+}$, the XRD analysis revealed that the entire phase was HAP (SrHAP). For phases with lower incorporation of $\mathrm{Sr}^{2+}$, the Sr-HAP (PDF 09-0432) phase was observed, and with increased incorporation, the SrHAP (PDF 34-0484) phase was observed, as shown in Figure 2. The crystallite size and crystallinity of samples A, B, and C were $48.8 \mathrm{~nm}$ and $99.60 \% ; 130 \mathrm{~nm}$ and $99.40 \%$; and $55 \mathrm{~nm}$ and $96.54 \%$, respectively. In the XRD analysis with $\mathrm{Sr}^{2+}$ doping, we observed that $\mathrm{Sr}^{2+}$ leads to an increase in crystallinity and crystal growth up to a certain concentration. Above that concentration, a decrease in crystallinity and the formation of other crystalline phases occurs. The substitution of $\mathrm{Sr}^{2+}$ in Ca sites produces distortion in the phosphate environment. Further $\mathrm{Sr}^{2+}$ incorporation may decrease the crystallinity and restrain the growth of SrHAP (Li et al., 2007). Since that the high crystallinity properties expected to be similar to dental enamel and a low crystallinity properties expected to be similar to bone mineral. Then, depending on the application of the material, you can choose the best option according to crystallinity and the incorporation of $\mathrm{Sr}^{2+}$ ions.

In the samples doped with $\mathrm{Mg}^{2+}$, an increase in the crystal size and crystallinity occur. However, at higher concentrations of $\mathrm{Mg}^{2+}$, causes a breakdown of the HAP in the crystal lattice, forming an amorphous material, which contains traces of beta tricalcium phosphate (bTCP), as observed in Figure 3. According to the literature, HAP doped with $\mathrm{Mg}^{2+}$ increases in crystal size and results in the appearance of $\beta$-TCP (whitlockite) (Ren et al., 2010). In our samples, a crystallographic phase transformation of HAP doped with $\mathrm{Mg}^{2+}$ into b-TCP occurred. In sample D with $\mathrm{Mg}^{2+}$, we observed a crystal size of $49.1 \mathrm{~nm}$ and crystallinity of $99.04 \%$. In studies where to correlate crystallinity and reactivity a-TCP, the results suggest that the $\mathrm{X}$-ray amorphous phase powder greatly contribute to its reactivity. Whereas the reactivity decrease as a function of strontium substitution for calcium (Boanini et al., 2010). Therefore, it is important to have that control in relation crystallinity and reactivity of the material. For while the crystallinity affects the bioactive material functions in conjunction with the ions influence increasing the bone. Then, should not be to saturate the incorporation of $\mathrm{Sr}^{2+}$ ions because it decreases reactivity.

As shown by the ICP-MS analysis results in table 1, the inclusion of $\mathrm{Mg}^{2+}$ occurred at $\mathrm{Ca}^{2+}$ sites and simultaneously caused phosphate release. At low concentrations, the HAP structure did not change. 


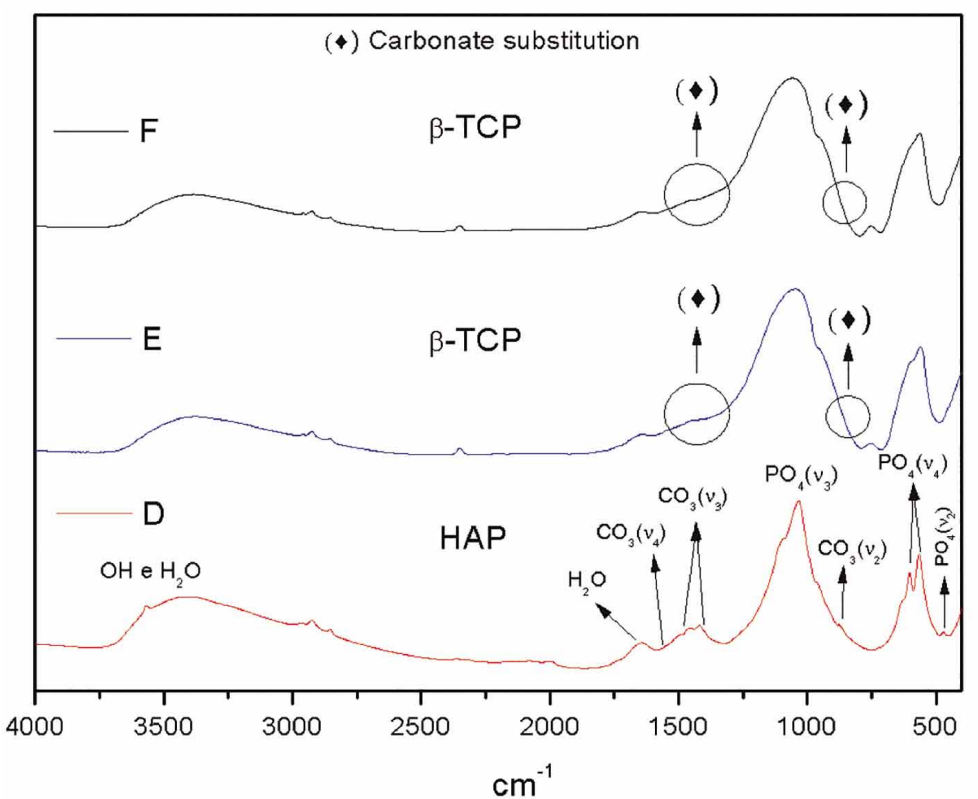

Fig. 2. FTIR spectra of samples (D), (E), and (F) after Mg ionic substitutions. Calcium phosphate vibrational bands are observed in spectrum D.

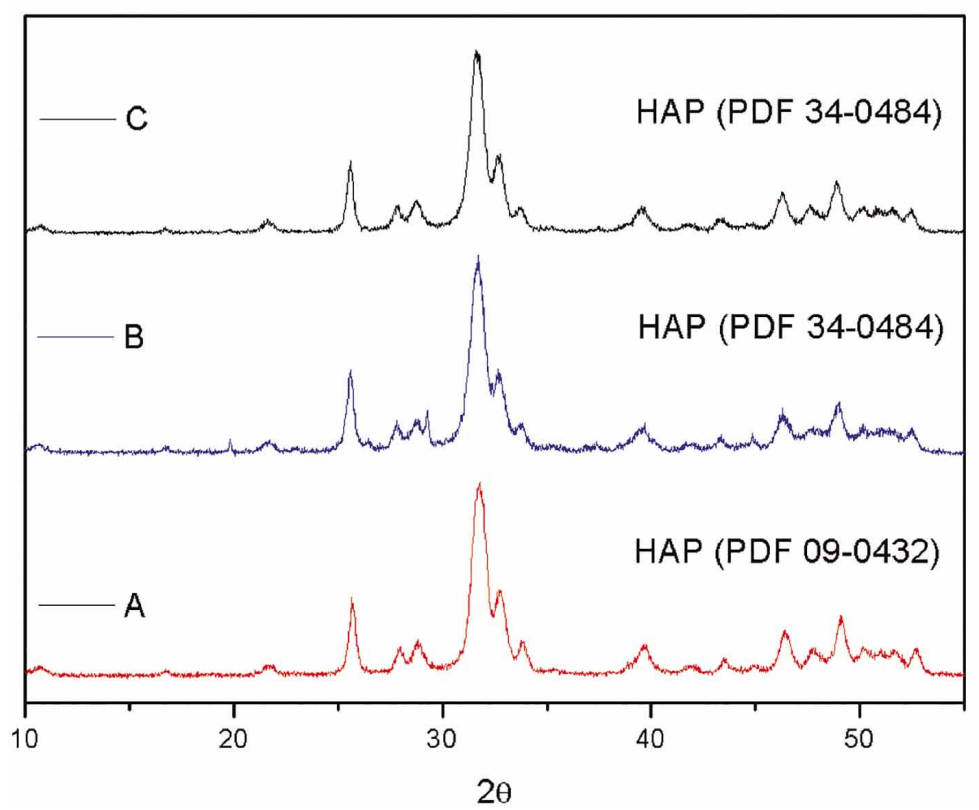

Fig. 3. XRD patterns of samples (A), (B), and (C) revealing HAP crystallographic phases after Sr ionic substitutions.

However, at higher concentrations, the $\mathrm{Ca} / \mathrm{P}$ ratio significantly decreased, which caused disorder in the crystal lattice and rearrangement of the $\beta$ TCP phase.

We can conclude that whether doping with $\mathrm{Sr}^{2+}$ or $\mathrm{Mg}^{2+}$, both the nanoparticle size and crystalline fraction increased during the calcium phosphate synthesis process. Beyond a minimum threshold of
$\mathrm{Sr}^{2+}$ inclusion, the crystallinity decreased, whereas with $\mathrm{Mg}^{2+}$ incorporation, the transformation of HAP into $\beta$-TCP occurred.

\section{ACKNOWLEDGMENTS}

This work was supported by CNPq, the Brazilian National Council for Scientific and Technological Development, and CAPES, the Brazilian Federal Agency for the Support and Evaluation of Graduate Education.

RABELO NETO, J. S.; KNOPF, T. B.; FREDEL, M. C.; OLATE, S. \& DE MORAES, P. H. Síntetis y caracterización del compuestos de fosfato de calcio con substituto de estroncio y magnesio. Int. J. Morphol., 33(3):1189-1193, 2015.

RESUMEN: Los biocerámicos ofrecen ventajas en la reparación y regeneración de tejidos duros utilizándose como relleno en cavidades óseas y como relleno particulado en cementos óseos de aplicaciones quirúrgicas. Regeneración y estimulación de la osteosíntesis a través de la liberación de iones esenciales, como el estroncio $(\mathrm{Sr})$ y magnesio $(\mathrm{Mg})$ es un campo relativamente nuevo. Por lo tanto, existe un gran interés en la investigación de diversas sustituciones iónicos sobre la estructura cristalográfica y las características para su uso en la prevención de osteoporosis y aumento de la formación ósea con disminuir la resorción ósea. En este estudio, se sintetizó muestras de fosfato de calcio con sustituciones iónicos Sr y Mg. Las muestras se caracterizaron usando difracción de rayos $\mathrm{X}$, espectroscopia infrarroja por transformada de Fourier, y la espectroscopia de masas con plasma acoplado inductivamente. Se observó hidroxiapatita, fosfato tricálcico beta, y las fases amorfas. Dependiendo de la sustitución iónica, el tamaño del cristal y cristalinidad variaron de $22 \mathrm{~nm}$ a $130 \mathrm{~nm}$ y de $84 \%$ a $99,6 \%$, respectivamente. La relación $\mathrm{Ca} / \mathrm{P}$ varió desde 0,72 hasta 1,82 . Los resultados demostraron el efecto de las inclusiones de $\mathrm{Sr}$ y $\mathrm{Mg}$ en fosfato de calcio en parámetros importantes que se utilizan en varias aplicaciones de biocerámicos.

PALABRAS CLAVE: Fosfato de calcio; Biomateriales; Biocerámica; Hidro-xiapatita.

\section{REFERENCES}

Boanini, E.; Panzavolta, S.; Rubini, K.; Gandolfi, M. $\&$ Bigi, A. Effect of strontium and gelatin on the reactivity of alpha-tricalcium phosphate. Acta Biomater., 6(3):936-42, 2010. 
Bouyer, E.; Gitzhofer, F. \& Boulos M. I. Morphological study of hydroxyapatite nanocrystal suspension. J. Mater. Sci. Mater. Med., 11(8):523-31, 2000.

Capuccini, C.; Torricelli, P.; Boanini, E.; Gazzano M.; Giardino, R. \& Bigi, A. Interaction of Sr-doped hydroxyapatite nanocrystals with osteoclast and osteoblast-like cells. $J$. Biomed. Mater. Res. A, 89(3):594-600, 2009.

da Cunha, M. R.; Laraia, I. O.; Franco, G. R.; Miguel, N. N.; Maciel, A. A.; dos Santos, G. R. \& Isayama, R. N. Osseointegration of hydroxyapatite implants in rat tibial defects with sciatic nerve injury. Int. J. Morphol., 33(2):620-5, 2015.

Dorozhkin, S. V. Calcium orthophosphates in nature, biology and medicine. Mater., 2(2):399-498, 2009.

Iafisco, M.; Ruffini, A.; Adamiano, A.; Sprio, S. \& Tampieri, A. Biomimetic magnesium-carbonate-apatite nanocrystals endowed with strontium ions as anti-osteoporotic trigger. Mater. Sci. Eng. C Mater. Biol. Appl., 35:212-9, 2014.

Landi, E.; Tampieri, A.; Celotti, G. \& Sprio, S. Densification behaviour and mechanisms of synthetic hydroxyapatites. J. Eur. Ceram. Soc,. 20(14-15):2377-87, 2000.

Landi, E.; Logroscino, G.; Proietti, L.; Tampieri, A.; Sandri, M. \& Sprio, S. Biomimetic Mg-substituted hydroxyapatite: from synthesis to in vivo behaviour. J. Mater. Sci. Mater. Med., 19(1):239-47, 2008.

Lee, T. Q.; Shapiro, T. A. \& Bell, D. M. Biomechanical properties of human tibias in long-term spinal cord injury. J. Rehabil. Res. Dev., 34(3):295-302, 1997.

Leventouri, T. Synthetic and biological hydroxyapatites: crystal structure questions. Biomaterials, 27(18):3339-42, 2006.

Li, Z. Y.; Lam, W. M. ; Yang, C.; Xu, B.; Ni, G. X.; Abbah, S. A.; Cheung, K. M. C.; Luk, K. D. K. \& Lu, W. W. Chemical composition, crystal size and lattice structural changes after incorporation of strontium into biomimetic apatite. Biomaterials, 28(7):1452-60, 2007.

Park, J. W.; Kim, Y. J.; Jang, J. H. \& Song. H. Positive modulation of osteogenesis- and osteoclastogenesis-related gene expression with strontium-containing microstructured $\mathrm{Ti}$ implants in rabbit cancellous bone. J. Biomed. Mater. Res. A, 101(1):298-306, 2013.

Ren, F.; Leng, Y.; Xin, R. \& Ge, X. Synthesis, characterization and ab initio simulation of magnesium-substituted hydroxyapatite. Acta Biomater., 6(7):2787-96, 2010.

Schumacher, M.; Henß, A.; Rohnke, M. \& Gelinsky, M. A novel and easy-to-prepare strontium(II) modified calcium phosphate bone cement with enhanced mechanical properties. Acta Biomater, 9(7):7536-44, 2013.
Shepherd, J. H.; Shepherd, D. V. \& Best, S. M. Substituted hydroxyapatites for bone repair. J. Mater. Sci. Mater. Med., 23(10):2335-47, 2012.

Ungureanu, D. N.; Angelescu, N.; Ion, R. M.; Stoian, E. V. \& Rizescu, C.Z. Synthesis and characterization of hydroxyapatite nanopowders by chemical precipitation. In: Bojkovic, Z; Kacprzyk, J.; Mastorakis, N.; Mladenov, V.; Revetria, R.; Zadeh, L. A. \& Zemliak, A. Recent Researches in Communications, Automation, Signal Processing, Nanotechnology, Astronomy and Nuclear Physics. Cambridge, World Scientific and Engineering Academy and Society Press, 2011. pp.296-301.

Weiner, S. \& Addadi, L. Design strategies in mineralized biological materials. J. Mater. Chem., 7(5):689-702, 1997.

Yao, F.; LeGeros, J. P. \& LeGeros, R. Z. Simultaneous incorporation of carbonate and fluoride in synthetic apatites: Effect on crystallographic and physico-chemical properties. Acta Biomater., 5(6):2169-77, 2009.

Zhang, H.; Liu, M.; Fan, H. \& Zhang, X. An efficient method to synthesize carbonated nano hydroxyapatite assisted by poly(ethylene glycol). Mater. Lett., 75:26-8, 2012.

\section{Correspondence to:}

MSc. José da Silva Rabelo Neto

Rua Arno Waldermar Döhler,957.

Zona Industrial Norte

CEP:89219-510

Joinville - SC

BRAZIL

Email: jsrabeloneto@gmail.com

Received: 28-05-2015

Accepted: 17-08-2015 